\title{
CKB wt Allele
}

National Cancer Institute

\section{Source}

National Cancer Institute. CKB wt Allele. NCI Thesaurus. Code C51052.

Human CKB wild-type allele is located within $14 q 32$ and is approximately $3 \mathrm{~kb}$ in length.

This allele, which encodes creatine kinase B-type protein, is involved in the reversible transfer of phosphate between ATP and phoshphogens wherein creatine phosphate is the primary substrate. 